\title{
Integração do enxerto heterólogo de pele humana no subepitélio da bolsa jugal do hamster (Mesocricetus auratus) ${ }^{1}$
}

\author{
Bernardo Hochman ${ }^{2}$ \\ Lydia Masako Ferreira ${ }^{3}$ \\ Flaviane Cássia Vilas Bôas \\ Mario Mariano 5
}

\begin{abstract}
Hochman B, Ferreira LM, Vilas Bôas FC, Mariano M. Integração do enxerto heterólogo de pele humana no subepitélio da bolsa jugal do hamster (Mesocricetus auratus). Acta Cir Bras (serial online) 2003 Set-Out;18(5). Disponível em URL: http://www.scielo.br/acb.
\end{abstract}

RESUMO - Objetivo: Descrever a integração de enxertos de pele total humana no subepitélio da bolsa jugal do hamster (Mesocricetus auratus) Métodos: A amostragem consistiu de 18 hamsters machos, exogâmicos, com 10 a 14 semanas de idade. Fragmentos de pele humana normal foram obtidos de pele excedente de mastoplastia redutora de paciente parda. Cada hamster foi enxertado em ambas as bolsas com fragmentos de pele, perfazendo um total de 36 fragmentos enxertados. Os animais foram distribuídos, em 6 grupos, para exame dos fragmentos enxertados com 5, 12, 21, 42, 84 e 168 dias. Uma avaliação macroscópica foi realizada comparando a bolsa contendo o fragmento enxertado em cada período com a mesma bolsa no pós-operatório imediato, mediante fotografias padronizadas. Na avaliação microscópica foi adotado como critério de integração a presença de vasos sangüíneos na derme dos enxertos. Observou-se também a presença de queratina, melanócitos, infiltrado celular e aspecto do tecido conjuntivo. Resultados: Na avaliação macroscópica foi observada uma reação vascular em torno dos fragmentos até 12 dias do implante, e a presença de pigmentação castanho-escura a partir de 42 dias. À microscopia, integraram-se 80,64\% dos fragmentos enxertados, inclusive no grupo de 168 dias. Observou-se infiltrado celular inflamatório até 12 dias, a presença de melanócitos a partir de 42 dias e uma hialinização do tecido conjuntivo após 84 dias. Conclusões: Fragmentos de pele humana integram-se no tecido celular subcutâneo da bolsa jugal do hamster, mantêm-se vascularizados por 168 dias, e conservam o epitélio íntegro até 21 dias. O subepitélio da bolsa representa modelo experimental de investigação da fisiologia de pele humana ex vivo.

DESCRITORES - Hamster. Mesocricetus. Transplante heterólogo. Transplante de pele.

\section{Introdução}

$\mathrm{O} 1^{\circ}$ Congresso Internacional de Xenotransplantes realizado em Minneapolis, USA, em 1991, estabeleceu um novo marco nas pesquisas de Imunobiologia em modelos animais experimentais. ${ }^{(1)}$ Dos modelos experimentais criados, foram e são utilizados para o estudo de heteroenxertos de pele humana camundongos denominados SCID mouse (Severed Combined Immunodeficiency Disease), geneticamente deficientes

1. Trabalho realizado na Disciplina de Imunologia do Departamento de Microbiologia, Imunologia e Parasitologia da Universidade Federal de São Paulo (UNIFESP), pelo Programa de Pós-Graduação em Cirurgia Plástica Reparadora da UNIFESP.

2. Mestre em Cirurgia Plástica e pós-graduando no Programa de Pós-Graduação em Cirurgia Plástica Reparadora da UNIFESP.

3. Professora Titular e Chefe da Disciplina de Cirurgia Plástica do Departamento de Cirurgia da UNIFESP, e Coordenadora do Programa de Pós-Graduação em Cirurgia Plástica Reparadora da UNIFESP.

4. Acadêmica do $6^{\circ}$ ano do curso de graduação em Medicina da UNIFESP.

5. Professor Titular do Instituto de Ciências Biomédicas do Departamento de Imunologia da Universidade de São Paulo, Professor Titular do Departamento de Patologia da Faculdade de Medicina Veterinária e Zootecnia da USP e Professor Visitante da Disciplina de Imunologia do Departamento de Microbiologia, Imunologia e Parasitologia da UNIFESP. 
em células-T e células-B, camundongos deficientes em células T com fenótipo CD4, e camundongos atímicos (nude mouse) com incompetência congênita, por mutação genética autossômica recessiva, de células T. Esses três modelos aceitam indefinidamente enxertos heterólogos de pele humana, ${ }^{(2)}$ sendo utilizado com maior freqüência o camundongo atímico (nude mouse).

Outros modelos experimentais também são utilizados para tal fim com menor sucesso. Camundongos Be-mouse (Beige), deficientes em células K (Killer) e NK (Natural Killer), apenas retardam a rejeição do heteroenxerto de pele humana até 12 dias. Camundongos XID mouse (X-Linked Immunodeficiency Disease), deficientes de células B e portadores de agamaglobulinemia, evitam a rejeição do enxerto até 5 dias. Com isso, os pesquisadores têm aproveitado as particularidades de cada um desses tipos de camundongos, criando "mutantes híbridos" mediante combinações entre esses animais. ${ }^{(2)}$

A imunodeficiência parcial ou total induzida nesses animais geneticamente manipulados determina alto grau de morbidade nos mesmos, tornando-os limitados ou até inaptos para certos tipos de pesquisa. $\mathrm{O}$ fato de precisarem para sua criação e manutenção de biotérios adequadamente estruturados com gaiolas mantidas em fluxo laminar, alimentação e água esterilizadas, condições de assepsia ambiental e instrumental rigorosas, além de laboratórios especializados, ${ }^{(3)}$ têm um custo operacional elevado e às vezes inexeqüível. ${ }^{(4)}$

Outros recursos são utilizados para possibilitar a integração de heteroenxertos em animais experimentais, porém com limitações. A timectomia em camundongos com 3 dias de idade pode tornar os animais inaptos para este tipo de investigação, à medida que desenvolvem doenças autoimunes multiorgânicas específicas, como gastrite, ooforite, orquite, tireoidite e pancreatite. ${ }^{(5)}$ A imunossupressão química acarreta inconvenientes tais, como a redução da imunidade celular e humoral, aumento da incidência de tumores espontâneos, diminuição da resistência dos animais a infecções virais, além de um custo operacional oneroso. ${ }^{(6,7)}$

Modelos de enxerto heterólogo que não requerem a indução de imunodeficiência, têm sido desenvolvidos utilizando os chamados "Locais de Privilégio Imunológico" (Immunlogically Privileged Sites). Um "Local de Privilégio Imunológico" é caracterizado pela falta de reconhecimento da carga antigênica do fragmento enxertado pelo linfonodo regional, por deficiência ou ausência de uma via anatômica aferente, evitando o início da resposta imune. ${ }^{(8)}$

Os "Locais de Privilégio Imunológico" mais investigados são a córnea, o cristalino ocular, câmara anterior do olho, cérebro, testículo, próstata e fígado. ${ }^{(9)}$ Foram também desenvolvidos "Locais de Privilégio Imunológico" artificiais, como tecido cicatricial, retalhos ilhados com pedículo vascular alinfático e câmaras de difusão com Millipore ${ }^{\circledR}{ }^{(9)}$

O hamster (Mesocricetus auratus) possui em cada lado das bochechas da cavidade oral uma bolsa. Essas bolsas são divertículos ou invaginações saculares distensíveis das mucosas jugais, que se estendem, sob a pele, da extremidade posterior da cavidade oral até aproximadamente o nível das escápulas do animal. A função principal dessas bolsas seria o armazenamento e transporte de alimento.

O epitélio da parede da bolsa é similar à pele humana, sendo denominado "pele sem folículos e glândulas". ${ }^{(10)}$ Apresenta camadas basais, espinhosas, granulares e córneas com queratinócitos, similar à epiderme ou epitélio da gengiva ou palato duro humano. ${ }^{(11,12)}$ O epitélio da bolsa apóia-se num subepitélio constituído por tecido conjuntivo areolar frouxo com ausência de vasos linfáticos, exceto na região proximal, onde se inserem as fibras do músculo retrator da bolsa. ${ }^{(13)}$ De há muito tem sido demonstrado que o tecido conjuntivo subepitelial da bolsa do hamster é um "Local de Privilégio Imunológico" natural. ${ }^{(14)}$

Cohen (1961) ${ }^{(14)}$ estudou na bolsa do hamster o processo de integração de enxerto de pele de coelhos. Os enxertos heterólogos sobreviveram e cresceram até a $6^{\mathrm{a}}$ semana, indistintamente se o grupo era de animais intactos ou imunodeprimidos. Observou, a partir da $3^{\mathrm{a}}$ semana, um encistamento de material celular e queratina entre a epiderme e a camada de epitélio da bolsa contígua ao mesmo. $\mathrm{O}$ autor também concluiu que o subepitélio das bolsas são, do ponto de vista imunológico, independentes entre si. Os eventos locais que ocorrem pela integração de homo ou heteroenxerto em uma bolsa, não tiveram repercussão nos enxertos da bolsa contralateral.

Haller, Billingham (1967), ${ }^{(15)}$ estudaram a origem da vascularização dos enxertos no subepitélio da bolsa jugal, por meio da isoenxertia heterotópica do epitélio da bolsa na parede torácica lateral dos animais. Sendo o epitélio da bolsa semelhante a uma "pele sem folículos ou anexos", os autores sugeriram que os resultados obtidos poderiam ser aplicados no processo de integração de enxertos de pele humana.

Kreider e col. (1971), ${ }^{(6)}$ no intuito de evitar o encistamento de queratina secretada pelo enxerto de pele total humana na bolsa jugal do hamster in situ, o qual poderia comprimir e achatar o próprio enxerto integrado, sugeriram a enxertia heterotópica do epitélio da bolsa para realizar estudos relativos a pele. 
Na literatura também são citados trabalhos onde se utilizou a bolsa jugal ou da bochecha para enxertar tecidos de doenças benignas e neoplasias malignas cutâneas, a fim de se estudar fisiopatologia e tratamento dessas doenças. ${ }^{(16,17)}$ Porém, a literatura é escassa e não suficientemente detalhada no que se refere ao estudo do enxerto total de pele humana na bolsa jugal do hamster.

Com base nessas informações, o presente estudo tem como objetivo descrever e analisar a integração do enxerto total de pele humana no subepitélio da bolsa jugal do hamster.

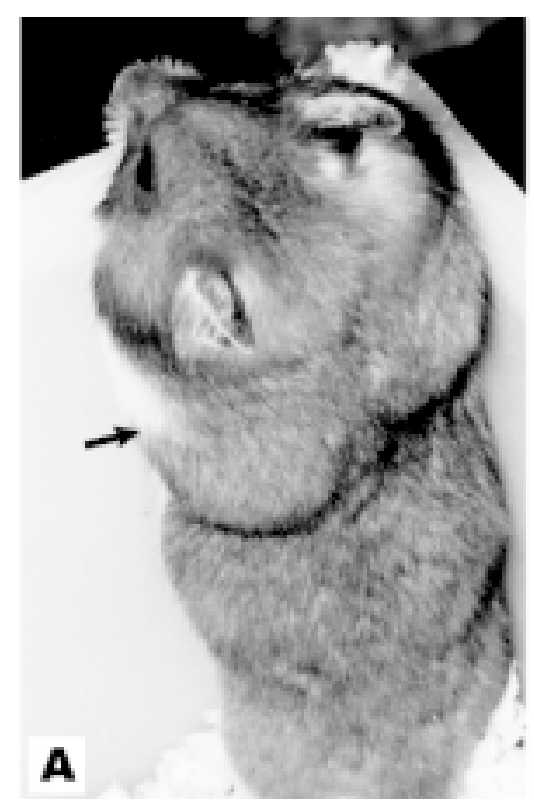

\section{Métodos}

Foram utilizados hamsters machos da espécie Mesocricetus auratus, também conhecida como hamster sírio dourado ou "esquilo do Líbano", exogâmicos ou exocriados (outbred), com 10 a 14 semanas de idade e com peso variando de 90 a 120 gramas (Figura 1). Foram provenientes do biotério do Centro de Desenvolvimento de Modelos Experimentais para Medicina e Biologia (CEDEME) da Universidade Federal de São Paulo - Escola Paulista de Medicina (UNIFESP-EPM). O laboratório da Disciplina de Imunologia da UNIFESPEPM foi sede dos procedimentos experimentais.

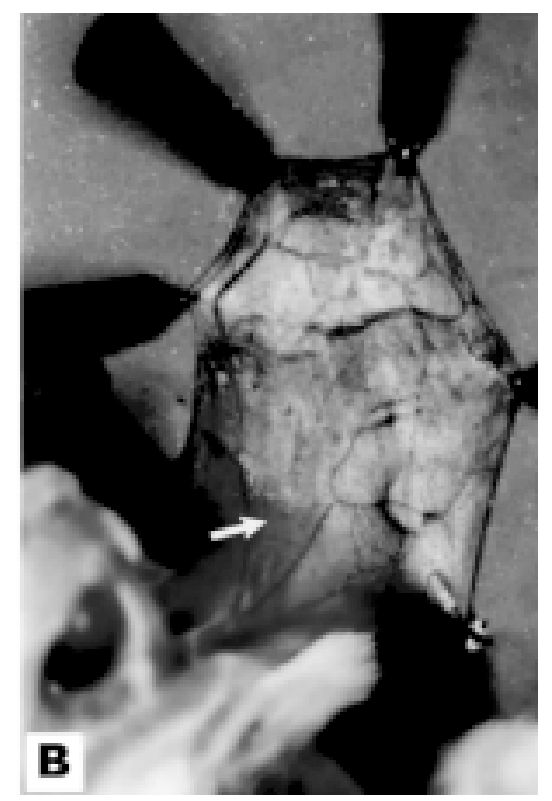

FIGURA 1 - Hamster sírio dourado (Mesocricetus auratus).

A - Animal com as bolsas jugais contendo alimento (seta).

B - Bolsa jugal evertida e distendida, evidenciando o músculo retrator da bolsa (seta).
Os animais foram mantidos em número de três, em gaiolas apropriadas de plástico com tampa superior metálica contendo ração própria e água potável $a d$ libitum. Foram formados 6 grupos experimentais com 3 animais em cada grupo. Cada hamster foi enxertado em ambas as bolsas com fragmentos de pele normal, perfazendo um total de 36 fragmentos enxertados. Os animais do Grupo A foram sacrificados para colher o material e submetê-lo a exame após cinco dias de enxertia. O Grupo B foi analisado com 12 dias, o Grupo C com 21 dias, o Grupo D com 42 dias, o Grupo E com 84 dias e o Grupo F com 168 dias.

Em relação à catalogação dos fragmentos enxertados, padronizou-se que o primeiro código do fragmento referia-se ao tipo de tecido estudado, no caso a letra $\mathrm{P}$ (pele). O segundo código foi relativo aos Grupos A a F. O terceiro código identificava o número do hamster de 1 a 3 dentro do grupo. O quarto código referia-se ao lado da bolsa, sendo a letra d para o enxerto na bolsa do lado direito e a letra e para a bolsa do lado esquerdo.

Utilizou-se pele normal humana da região mamária de paciente proveniente da Disciplina de Cirurgia Plástica do Departamento de Cirurgia da UNIFESP-EPM, do sexo feminino de cor não-branca, a partir do tecido periareolar excedente de mastoplastia redutora realizada no Hospital São Paulo. O critério de exclusão para a obtenção da paciente doadora da pele abrangeu o relato ou existência atual ou pregressa de qualquer anormalidade da cicatrização cutânea em qualquer região do corpo da paciente, como cicatrizes hipertróficas e/ou queloideanas, ou a existência na paciente de doenças metabólicas, doenças do tecido conjuntivo e auto-imunes.

O tecido cutâneo foi transportado da sala de operação ao laboratório experimental dentro de frasco 
estéril contendo solução fisiológica a $0,9 \%$, abrigado em recipiente de poliestireno (Isopor ${ }^{\circledR}$ ) contendo gelo. O tempo entre a colheita do material e o transplante no último animal experimental foi de até 8 horas. Foi completada no laboratório, com tesoura de íris curva, a ressecção do tecido subcutâneo remanescente na pele oriunda da sala de operação. Os fragmentos para enxertia foram obtidos de toda a superfície epitelizada da amostra cutânea, com o uso de um punch circular de $2 \mathrm{~mm}$ de diâmetro. Após todos os fragmentos de pele terem sido obtidos, permaneceram imersos em receptáculo de plástico contendo solução fisiológica a $0,9 \%$ dentro do mesmo recipiente de Isopor ${ }^{\circledR}$ com gelo, aguardando o momento da enxertia.

As operações foram realizadas nos animais sob anestesia geral, por injeção intraperitoneal de uma associação de Cloridrato de 2-(2,6-xilidino)-5,6-dihidro4H-1,3-tiazina $\left(\right.$ Rompun $\left.^{\circledR}\right)$ na dosagem de $0,1 \mathrm{ml} / \mathrm{Kg}$ e Cloridrato de Quetamina $\left(\right.$ Francotar $\left.^{\circledR}\right)$ na dosagem de $0,075 \mathrm{ml} / \mathrm{Kg}$. Os procedimentos operatórios não seguiram o rigor das normas convencionais de antissepsia e assepsia. Usaram-se luvas de procedimento de látex não estéreis para proteção da equipe.

As bolsas jugais foram lavadas pela cavidade oral por meio de jatos de água injetados por meio de seringa de plástico sem agulha, a fim de retirar resíduos alimentares ou de serragem acumulados. A seguir, cada bolsa foi exteriorizada por manobra de eversão com 2 pinças de Adson-Brown, deixando-a distendida mediante fixação com agulhas de tamanho 13 x 4,5 na superfície do campo operatório de Isopor $^{\circledR}$ revestido com campo.

Uma incisão de $5 \mathrm{~mm}$ foi realizada em área avascular mais proximal da primeira camada epitelial (ou camada superior) da parede da bolsa, de forma a não atingir fibras do músculo retrator da bolsa que se inserem no terço proximal da mesma, com o intuito de evitar o possível contato com vasos linfáticos. ${ }^{(13)} \mathrm{Com}$ auxílio de tesoura de dissecção delicada foi realizada uma divulsão romba, em túnel, no tecido conjuntivo em sentido distal à bolsa (ou seja, em sentido oposto à boca do animal) (Figuras 2-A a 2-C).
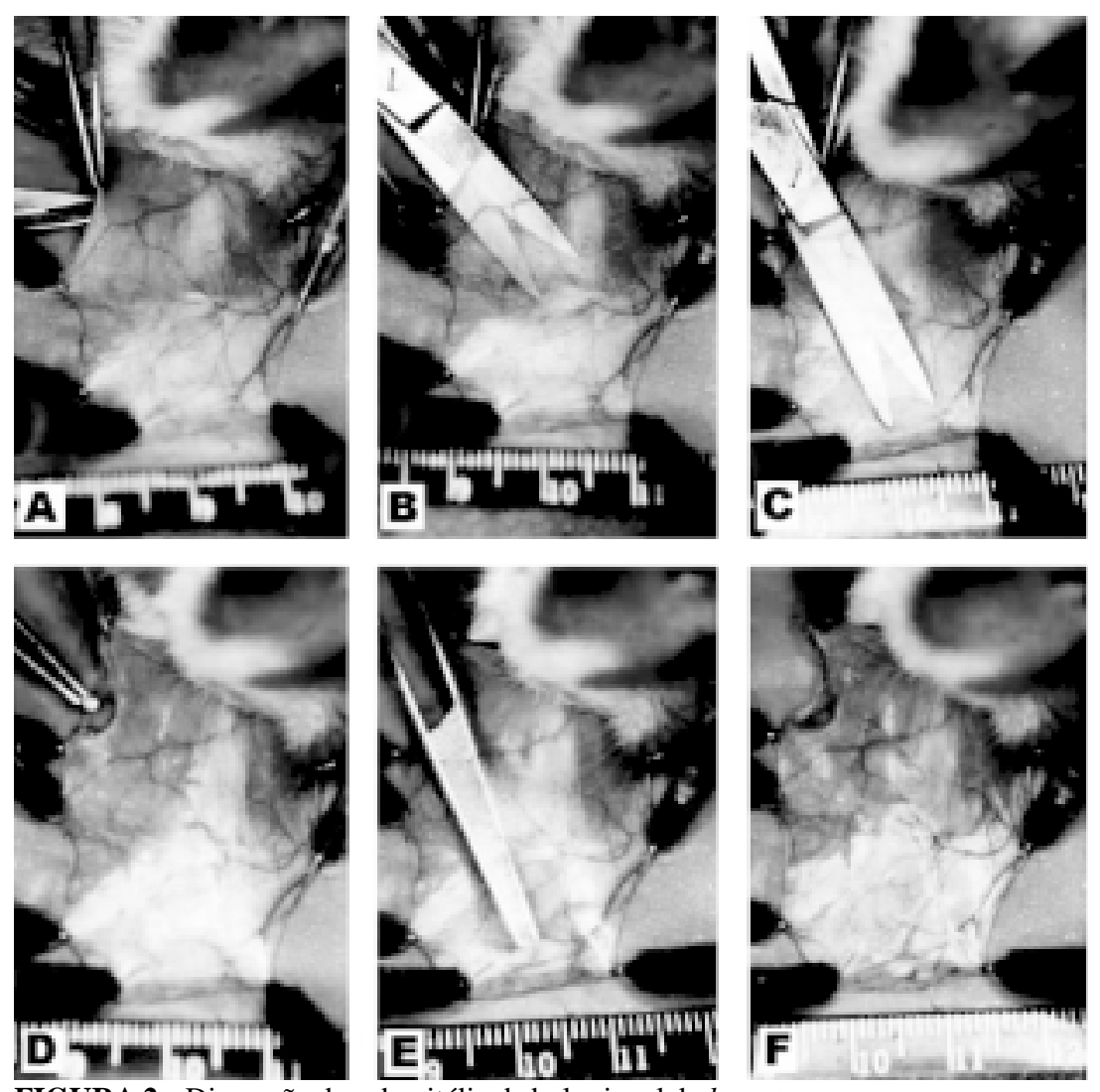

FIGURA 2 - Dissecção do subepitélio da bolsa jugal do hamster.

A - Pinçamento da primeira camada epitelial da parede da bolsa.

B - Incisão em área avascular e divulsão romba no subepitélio, em túnel, em direção ao ponto mais distal da bolsa.

C - Divulsão completada até o ponto mais distal da bolsa, sem perfurá-la.

$\mathrm{D}$ - O fragmento de pele é introduzido, pela incisão da divulsão do túnel, por meio de uma pinça fina e longa.

$\mathrm{E}$ - O fragmento é posicionado na posição mais distal da bolsa.

F - Fragmento de pele após estar "acomodado" pela compressão digital do epitélio circunjacente. 
Com uma pinça fina e longa, o fragmento de pele foi introduzido entre as duas camadas do epitélio da bolsa (posição intramural), no local mais distal da mesma. Uma vez posicionado o fragmento enxertado, com o dedo indicador comprimiu-se levemente o fragmento de pele entre as duas camadas epiteliais da parede da bolsa, para permitir que o mesmo se fixasse naturalmente pelo tecido conjuntivo areolar circunjacente (Figuras 2-D a 2-F). A incisão do epitélio foi fechada por simples coaptação bi-digital das margens da ferida, e a seguir invaginou-se a bolsa para dentro da cavidade oral. Os animais foram encaminhados ao biotério após a recuperação anestésica.

À época de colheita, por grupo, para exame dos fragmentos de pele enxertados, cada animal foi novamente anestesiado, e as bolsas foram lavadas, exteriorizadas, distendidas e fixadas no campo operatório seguindo os mesmos procedimentos realizados durante a fase de enxertia. Depois de serem realizadas as observações macroscópicas, as bolsas foram ressecadas com tesoura de íris reta ao nível do músculo retrator. A seguir, os animais, ainda sob anestesia geral, foram submetidos à eutanásia por inalação de éter sulfúrico.

\section{Avaliação macroscópica dos fragmentos enxertados}

Antes de ressecar o fragmento de cada bolsa jugal contendo o fragmento de pele, com o animal ainda anestesiado e vivo, foram observadas e fotografadas de forma padronizada, todas as bolsas em todos os tempos operatórios, ou seja, desde o dia em que as amostras foram enxertadas até o último grupo de animais com 168 dias de enxertia.

Todas as fotografias foram obtidas com uma câmera fotográfica monoreflex Pentax ${ }^{\circledR}$ modelo K-1000, com objetiva de distância focal de $50 \mathrm{~mm}$, ajustada em sua distância mínima ao foco com $45 \mathrm{~cm}$, e acoplada com 2 lentes close-up de +3 e +2 dioptrias, nesta ordem, perfazendo +5 dioptrias de aproximação.

Foram utilizados filmes coloridos de $135 \mathrm{~mm}$ de sensibilidade ISO 100, e após serem revelados, as fotografias foram ampliadas em papel fotográfico de $10 \times 15 \mathrm{~cm}$ de tamanho. A máquina fotográfica foi ajustada com uma abertura de diafragma de 5,6 e velocidade de abertura de 1/60 segundos, sendo nela acoplada um flash circular (ring flash) da marca Starblitz $^{\circledR}$, regulado com sensor automático de luz. Para melhor visibilizar pormenores dos transplantes nas bolsas e nos enxertos, as fotografias foram examinadas por meio de uma lente com aumento de 4 vezes, contendo um foco de luz fluorescente incorporado.

Além das observações anotadas na ficha de cada animal durante o ato operatório, foram comparadas, para cada bolsa jugal, as fotografias obtidas logo após os transplantes das amostras, com as fotografias em cada tempo operatório da obtenção dos enxertos para análise. Foram anotados os seguintes quesitos: (A) "presença do enxerto", (B) "presença de pigmentação escura no enxerto", (C) "vascularização circunjacente ao enxerto" e (D) "presença de ramo vascular na direção do enxerto". Foi também observado o aspecto da incisão de cada bolsa por onde se introduziu o fragmento, e a presença de alterações nas bolsas, como secreção, supuração ou aderências.

Os quesitos (A) "presença do enxerto" e (B) "presença de pigmentação escura no enxerto" foram avaliados como "ausente" (-) ou "presente" (+). Os quesitos $(\mathrm{C})$ "vascularização circunjacente ao enxerto" e (D) "presença de ramo vascular na direção do enxerto", foram avaliados de forma subjetiva semiquantitativa pelo pesquisador, utilizando uma escala arbitrada para cada um desses dois quesitos (Tabela 1).

TABELA 1 - Critérios macroscópicos de avaliação dos enxertos.

\begin{tabular}{ll}
\hline A $)$ & PRESENÇA DO ENXERTO \\
- & Ausente \\
+ & Presente \\
$(B)$ & PRESENÇA DE PIGMENTAÇÃO ESCURA NO ENXERTO \\
- & Ausência de pigmentação \\
+ & Presença de pigmentação \\
$($ C $)$ & VASCULARIZAÇÃO CIRCUNJACENTE AO ENXERTO \\
0 & Ausência de vascularização circunjacente \\
+ & Vascularização restrita a um pequeno setor ao redor do enxerto \\
++ & Vascularização abrangendo quase toda a periferia do enxerto \\
+++ & Vascularização ao redor de todo o enxerto \\
$($ D) & PRESENÇA DE RAMO VASCULAR NA DIREÇÃO DO ENXERTO \\
0 & Ausência de ramos vasculares na direção do enxerto \\
+ & Presença de 1 ramo vascular principal \\
++ & Presença de 2 ramos vasculares principais \\
+++ & Presença de 3 ramos vasculares principais \\
\hline
\end{tabular}

Legenda: $0 \mathrm{a}+++=$ intensidade 
Técnica de preparo dos exames histológicos e parâmetros microscópicos

Padronizou-se o preparo da amostra a ser enviada para exame, com o intuito de orientar o técnico do laboratório de histologia a localizar o fragmento enxertado, às vezes de difícil visibilização pela desidratação decorrente da fixação.

Na época da colheita do material, os fragmentos ressecados das bolsas contendo o fragmento de pele enxertado, foram dispostos sobre um pequeno pedaço de Isopor $^{\circledR}$ com agulhas 13 x 4,5 (cor marrom) e uma agulha diferente ( $30 \times 8$ ou cor verde), disposta justadistalmente ao fragmento enxertado em relação à porção proximal da bolsa, para facilitar a localização do mesmo após sua fixação. A seguir, as bolsas assim dispostas, foram fixadas em frascos com formol a $12 \%$. Os frascos foram envoltos em papel-alumínio para prevenir a fotodegradação do formol. Após 48 horas de fixação, o segmento da bolsa contendo o fragmento enxertado foi separado do restante da bolsa pela obtenção de um novo segmento de bolsa de forma retangular. Um dos lados maiores desse retângulo foi secionado tangencialmente ao fragmento de pele enxertado, ou seja, na altura do orifício deixado pela agulha diferente ( $30 \times 8$ ou cor verde), e no lado maior contralateral foi recortado um pequeno triângulo, simulando uma seta apontando o lado onde está o fragmento enxertado (Figura 3). Os segmentos retangulares de bolsa foram enviados ao laboratório de histologia em tubos com formol a $12 \%$, e também protegidos da luz.
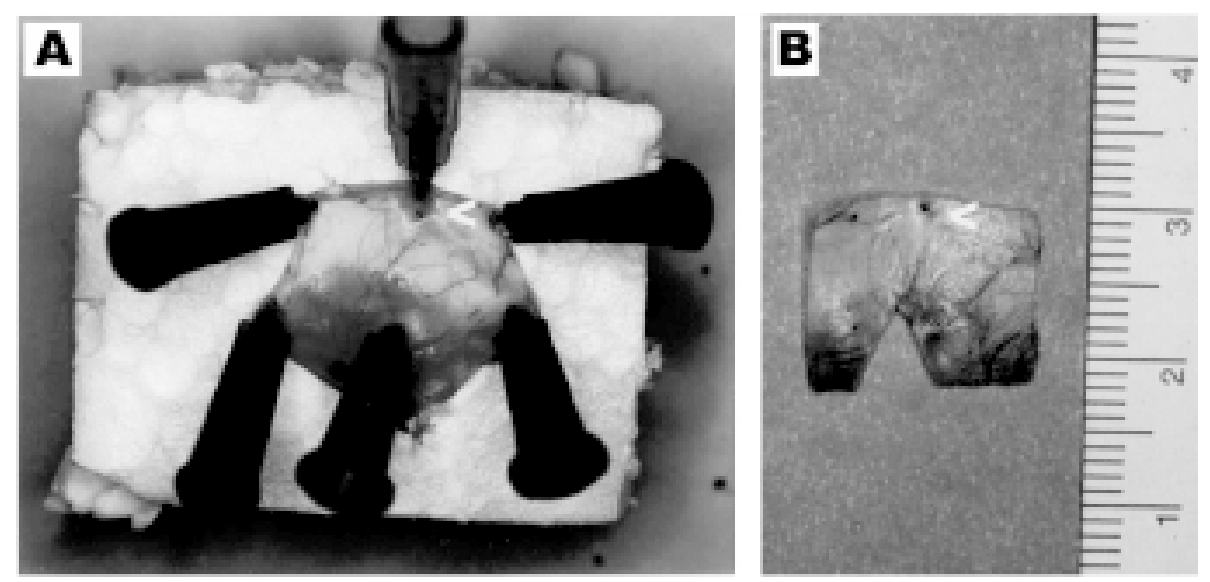

FIGURA 3 - Preparo da bolsa, com localização do fragmento enxertado, para o exame microscópico.

A - O fragmento excisado da bolsa é distendido e fixado sobre uma base de Isopor $^{\circledR}$, e o local do fragmento enxertado é marcado com uma agulha (seta), diferente às demais, em ponto justadistal ao mesmo.

B - Após 2 dias de formolização, a bolsa é recortada, de forma retangular, tangenciando o orifício deixado pela agulha de referência (seta), num plano paralelo à linha representada pela inserção do músculo retrator da bolsa na primeira camada epitelial da parede da bolsa. Excisa-se a bolsa de forma triangular, no lado oposto ao fragmento enxertado, simulando uma seta que aponta para o mesmo, onde serão iniciados os cortes pelo micrótomo.

No laboratório, os segmentos retangulares de bolsa contendo o fragmento enxertado foram desidratados com álcool crescente, diafanizados com xilol, incluídos em parafina com ponto de fusão entre 56 a $58^{\circ} \mathrm{C}$, submetidos a micrótomo regulado para uma espessura de $5 \mu \mathrm{m}$ e as lâminas coradas pela técnica de Hematoxilina-Eosina.

\section{Avaliação microscópica dos fragmentos enxertados}

A investigação histológica foi realizada com um microscópio de luz da marca Olympus ${ }^{\circledR}$ modelo BX60.
Foram utilizadas as objetivas 20 x $0,50 \mathrm{Ph} 1$ e $40 \mathrm{x}$ $10,75 \mathrm{Ph} 2$ do microscópio, por meio de visor binocular com aumento de 10 vezes, obtendo-se uma ampliação final de 200 e 400 vezes, respectivamente. Foi realizada varredura linear e seqüencial em sentido horário dos campos microscópicos.

Foi considerado como parâmetro principal de indicação da integração dos fragmentos de pele enxertados, a (A) "presença de vasos" sangüíneos na região periférica e central do fragmento, contendo, obrigatoriamente, hemácias nos lumens. Vasos sangüíneos localizados no limite da região periférica, ou fora desta, foram considerados como pertencentes ao hospedeiro. 
Outros quesitos analisados nos fragmentos de pele enxertados foram: (B) "presença de infiltrado inflamatório (representado por células mononucleares e/ou polimorfonucleares)" e (C) "presença de melanócitos" (Cohen, 1961). ${ }^{(14)}$ Foram também feitas observações a respeito da (D) "presença do epitélio" no enxerto e do (E) "aspecto do colágeno" do tecido conjuntivo.

Os quesitos (A) "presença de vasos", (B) "presença de infiltrado inflamatório" e (C) "presença de melanócitos" foram inicialmente avaliados, individualmente por amostra, como "ausente" (-) ou "presente" (+).

\section{Resultados}

\section{Macroscopia}

Em todas as bolsas jugais dos hamsters foi possível visibilizar os fragmentos de pele enxertados. Observou- se que a partir dos enxertos de pele do Grupo A (5 dias), as incisões na parte proximal das bolsas, por onde se introduziram os fragmentos, já estavam cicatrizadas. Somente em duas bolsas houve complicações nas incisões. No enxerto P-A1d ocorreu reação inflamatória com hiperemia e retração da região do epitélio vizinho à incisão, e no enxerto $\mathrm{P}-\mathrm{A} 3 \mathrm{~d}$ havia, no local da incisão, a presença de pouca secreção amareloesbranquiçada e uma falta de coaptação parcial da incisão. Ao redor da incisão notou-se reação inflamatória, caracterizada por hiperemia e congestão vascular da região da bolsa onde está inserido o músculo retrator da bolsa, não atingindo a região da bolsa onde estava localizado o fragmento de pele enxertado (Figura 4).
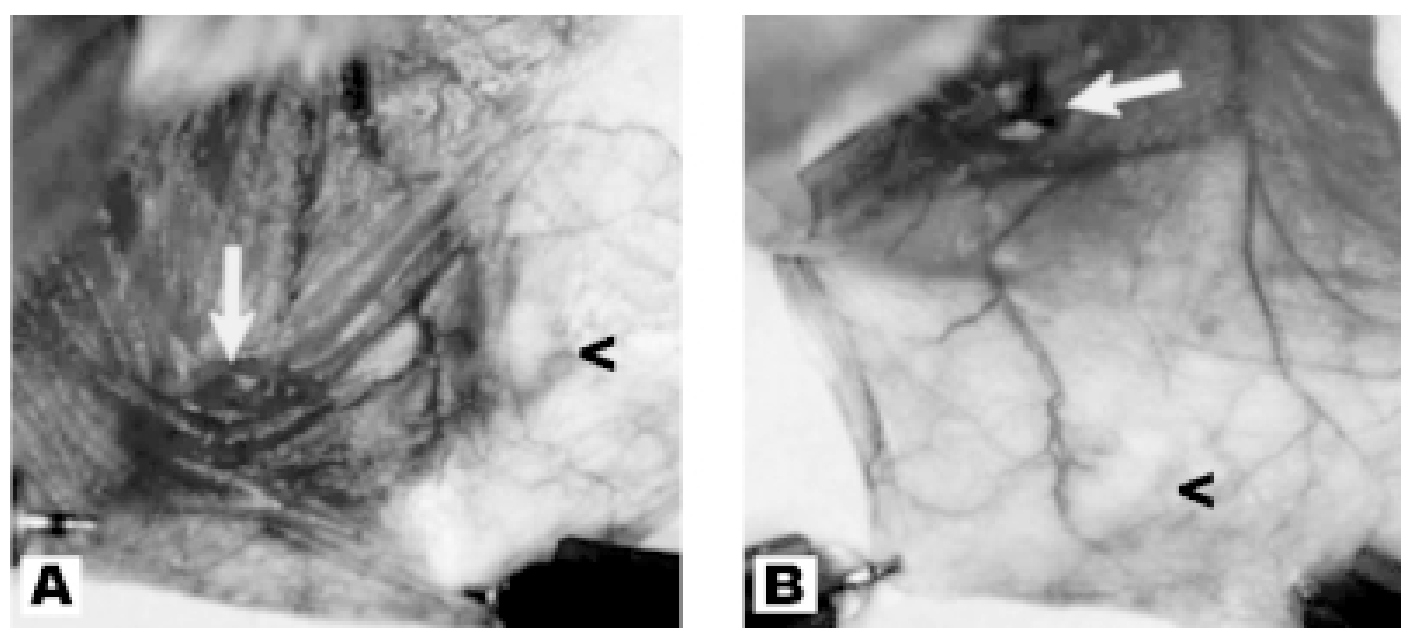

FIGURA 4 - Complicações nas incisões das bolsas enxertadas com pele aos 5 dias.

A - Reação inflamatória com retração no local da incisão (P-A1d).

B - Presença de discreta secreção com cicatrização parcial da incisão (P-A3d). (> = enxerto; seta = local da incisão com complicação)

A vascularização da bolsa circunjacente ao fragmento de pele enxertado (quesito $\mathrm{C}$ ) e a presença de ramo(s) vascular(es) em direção ao enxerto (quesito D), esteve presente no Grupo A (5 dias) e no Grupo B (12 dias), estando ausente nos demais grupos, exceto nos enxertos P-C3d e P-C3e (21 dias).
Em relação ao ramo vascular em direção ao enxerto, houve predomínio no Grupo A (5 dias) de um vaso sangüíneo pré-existente que sofreu ectasia, e também isoladamente na bolsa P-E2d (84 dias). No Grupo B (12 dias) ocorreu predomínio quanto ao aparecimento de um vaso sangüíneo que não foi antes identificado com destaque (Figuras 5-A e 5-B). 

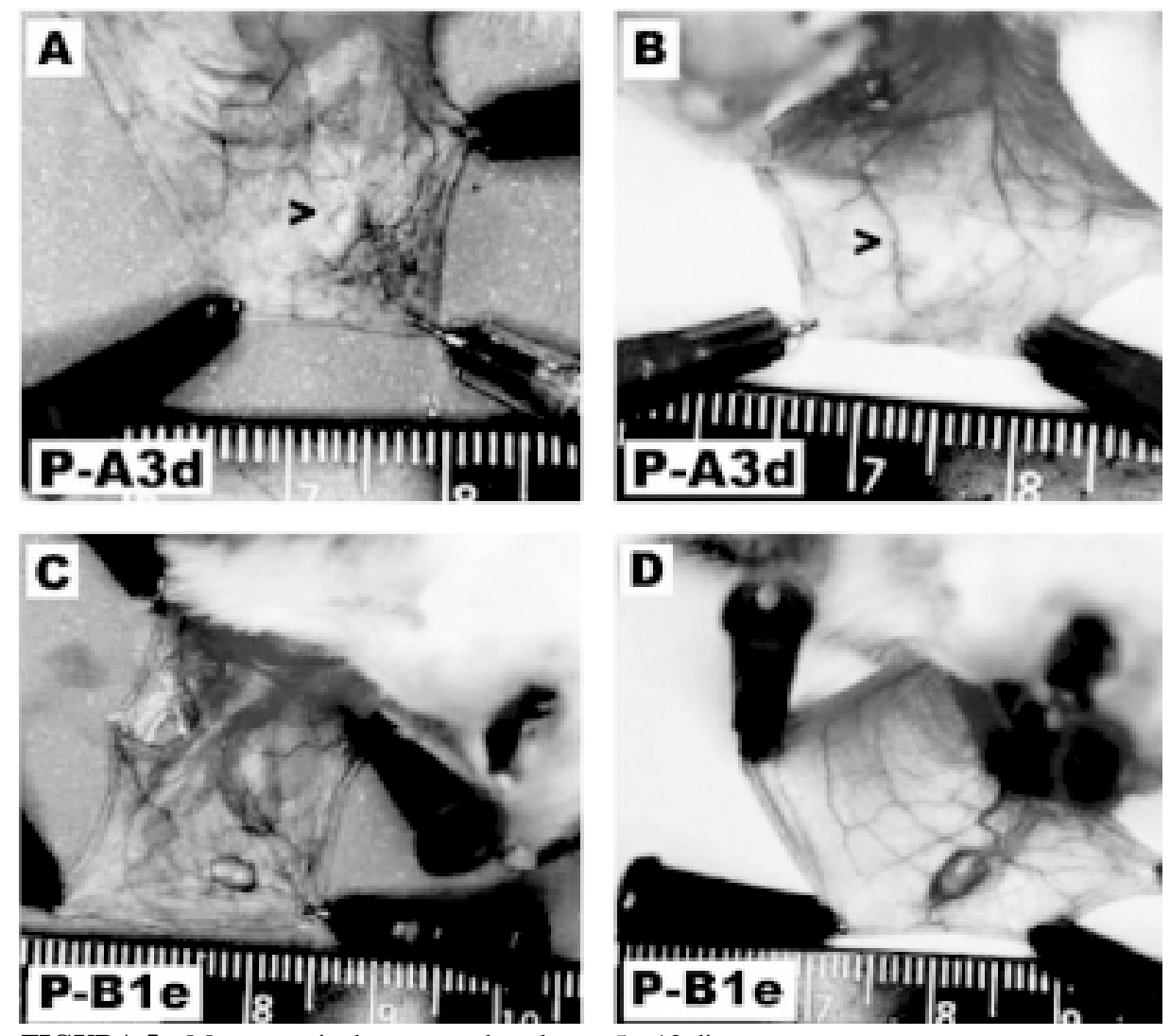

FIGURA 5 - Macroscopia do enxerto de pele aos 5 e 12 dias.

A - Pós-operatório imediato de animal do Grupo A, e detalhe da bolsa com ramo vascular em direção ao enxerto.

B - Aos 5 dias, ectasia desse mesmo vaso sangüíneo pré-existente em direção ao fragmento enxertado, porém sem vascularização circunjacente (no detalhe, > = ramo vasodilatado). C - Pós-operatório imediato de animal do Grupo B.

D - Aos 12 dias, vascularização circunjacente ao fragmento de pele enxertado intensa “+++", e aparecimento de um vaso dilatado em direção ao enxerto não identificável no pós-operatório imediato.

A partir do Grupo C (21 dias) houve uma súbita diminuição da vascularização da bolsa ao redor do fragmento enxertado. Observou-se a presença de pigmentação de coloração castanho-escura, ora puntiforme,
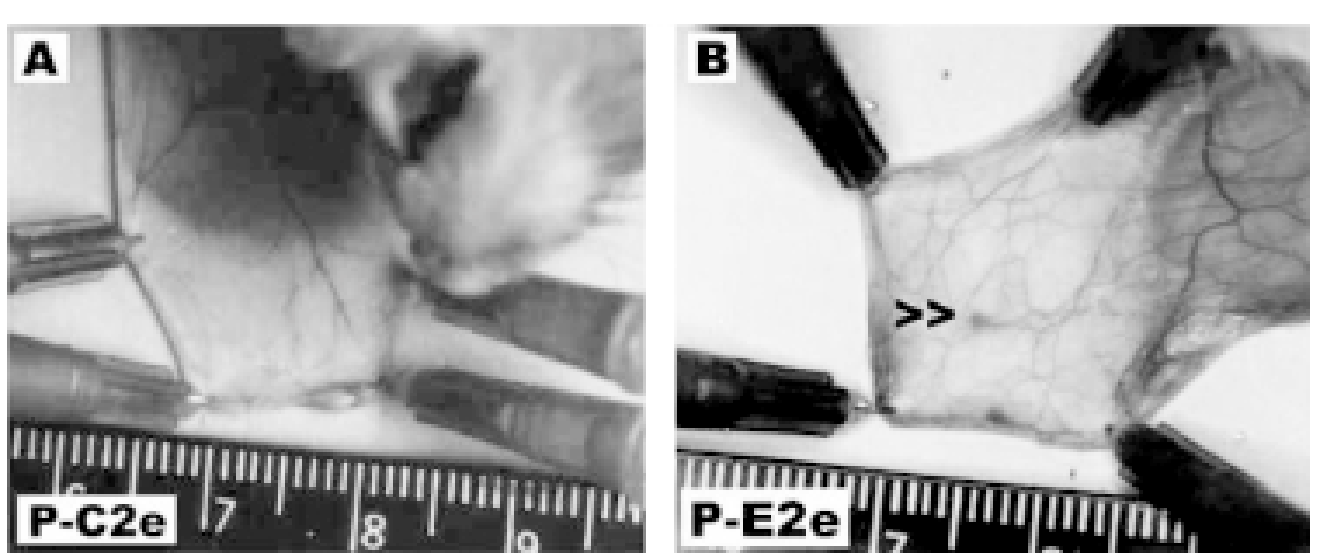

FIGURA 6 - Macroscopia do enxerto de pele aos 21 e 84 dias.

A - Aos 21 dias, observa-se ausência de reação vascular na bolsa e ao redor do fragmento enxertado.

B - Aos 84 dias, observa-se a presença de pigmentação castanho-escura no fragmento de pele enxertada (seta $>$ ). partir da primeira amostra do $42^{\circ}$ dia pós-operatório $(\mathrm{P}-$ D1d), até a última do $168^{\circ}$ dia pós-operatório (P-F1e), exceto no fragmento P-F1e (Figura 6). 
Os resultados macroscópicos dos enxertos de pele estão descritos na Tabela 2 e na Figura 7.

TABELA 2 - Descrição dos exames macroscópicos nos enxertos de pele.

\begin{tabular}{|c|c|c|c|c|c|}
\hline $\begin{array}{l}\text { TEMPODE } \\
\text { ENXERTIA } \\
\text { (dias) }\end{array}$ & $\begin{array}{c}\text { ENXERTO } \\
\text { DE } \\
\text { PELE }\end{array}$ & $\begin{array}{c}\text { PRESENÇA } \\
\text { ENXERTO } \\
\text { ( A ) }\end{array}$ & $\begin{array}{c}\text { PIGMENTAÇÃO } \\
\text { ( B ) }\end{array}$ & $\begin{array}{c}\text { VASCULARIZAÇÃO } \\
\text { CIRCUNJACENTE } \\
\text { ( C ) }\end{array}$ & $\begin{array}{c}\text { RAMO } \\
\text { VASCULAR } \\
\text { ( D ) }\end{array}$ \\
\hline 5 & P-A1d & + & - & 0 & 0 \\
\hline 5 & P-Ale & + & - & + & + \\
\hline 5 & P-A2d & + & - & ++ & $(+)$ \\
\hline 5 & P-A2e & + & - & +++ & $(+)$ \\
\hline 5 & P-A3d & + & - & 0 & $(+)$ \\
\hline 5 & P-A3e & + & - & + & $(+)$ \\
\hline 12 & P-B1d & + & - & ++ & 0 \\
\hline 12 & P-B1e & + & - & +++ & + \\
\hline 12 & P-B2d & + & - & ++ & + \\
\hline 12 & P-B2e & + & - & ++ & $(+)$ \\
\hline 12 & P-B3d & + & - & + & + \\
\hline 12 & P-B3e & + & - & ++ & 0 \\
\hline 21 & P-C1d & + & - & 0 & 0 \\
\hline 21 & $\mathrm{P}-\mathrm{C} 1 \mathrm{e}$ & + & - & 0 & 0 \\
\hline 21 & $\mathrm{P}-\mathrm{C} 2 \mathrm{~d}$ & + & - & 0 & 0 \\
\hline 21 & $\mathrm{P}-\mathrm{C} 2 \mathrm{e}$ & + & - & 0 & 0 \\
\hline 21 & P-C3d & + & - & 0 & + \\
\hline 21 & P-C3e & + & - & 0 & + \\
\hline 42 & P-D1d & + & + & 0 & 0 \\
\hline 42 & P-D1e & + & + & 0 & 0 \\
\hline 42 & P-D2d & + & + & 0 & 0 \\
\hline 42 & $\mathrm{P}-\mathrm{D} 2 \mathrm{e}$ & + & + & 0 & 0 \\
\hline 42 & P-D3d & + & + & 0 & 0 \\
\hline 42 & P-D3e & + & + & 0 & 0 \\
\hline 84 & P-E1d & + & + & 0 & 0 \\
\hline 84 & P-E1e & + & + & 0 & 0 \\
\hline 84 & P-E2d & + & + & 0 & $(+)$ \\
\hline 84 & P-E2e & + & + & 0 & 0 \\
\hline 84 & P-E3d & + & + & 0 & 0 \\
\hline 84 & P-E3e & + & + & 0 & 0 \\
\hline 168 & P-F1d & + & + & 0 & 0 \\
\hline 168 & P-F1e & + & - & 0 & 0 \\
\hline 168 & P-F2d & + & + & 0 & 0 \\
\hline 168 & P-F2e & + & + & 0 & 0 \\
\hline 168 & P-F3d & + & + & 0 & 0 \\
\hline 168 & P-F3e & + & + & 0 & 0 \\
\hline
\end{tabular}

Parâmetros: $\underline{\mathrm{A}}$ e $\underline{\mathrm{B}}:-/+=$ ausência / presença $; \underline{\mathrm{C}}: 0 \mathrm{a}+++=$ intensidade; $\underline{\mathrm{D}}: 0$ ou $+=$ quantidade $\mathrm{e}$ $(+)=$ presença de vaso sangüineo pré-existente, no pós-operatório imediato, com ectasia. 

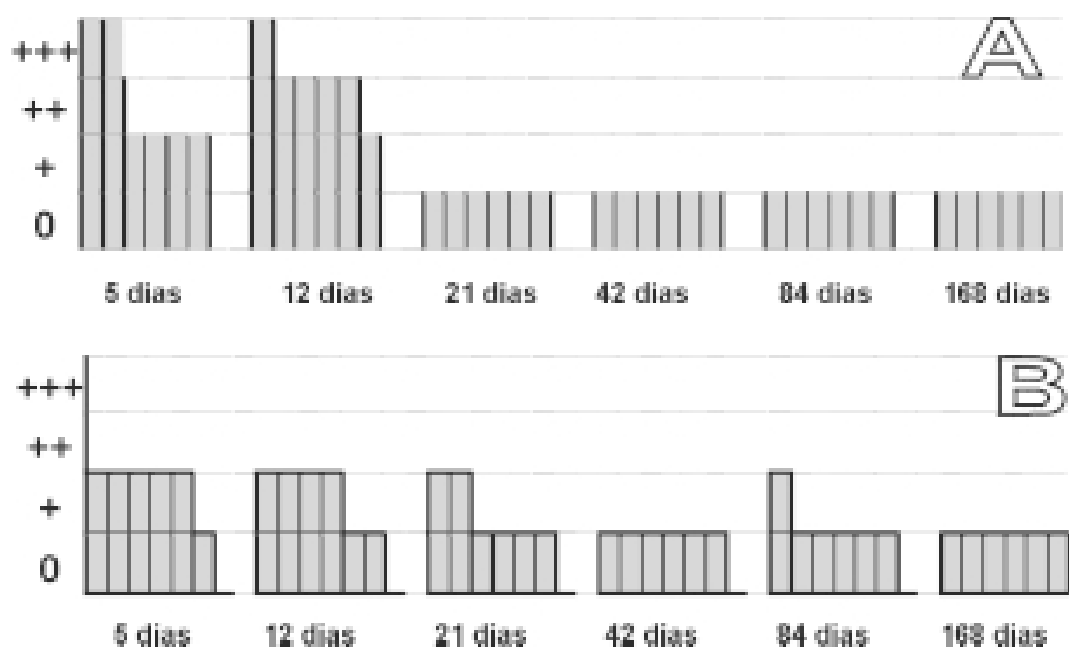

FIGURA 7 - Fenômenos vasculares macroscópicos nos enxertos de pele.

Representação dos eventos vasculares macroscópicos dos grupos, por período de 5,

12, 21, 42, 84 e 168 dias:

A - vascularização circunjacente ao enxerto;

$\mathrm{B}$ - presença de ramo vascular em direção ao enxerto.

\section{Microscopia}

O exame microscópico demonstrou a presença do enxerto em apenas 31 bolsas. Em 5 lâminas o fragmento de pele enxertado estava ausente no espaço subepitelial (P-A1e, P-A2e, P-D2d, P-D3e e P-F2e). De um total de 31 bolsas, não foi constatada a presença de vasos e, por conseguinte, a integração do enxerto, em 6 bolsas ( 1 no Grupo de 5 dias, 3 no Grupo com 12 dias e 2 no Grupo de 21 dias).

No Grupo A (5 dias) fragmentos de pele enxertados apresentaram epitélio íntegro com queratina, e melanócitos advindos do ser humano em desagregação. $\mathrm{O}$ tecido conjuntivo apresentou vasos com aspecto pletórico. Foi notada a presença de discreto infiltrado misto de células mononucleares e polimorfonucleares no Grupo B (12 dias) (Figura 8).
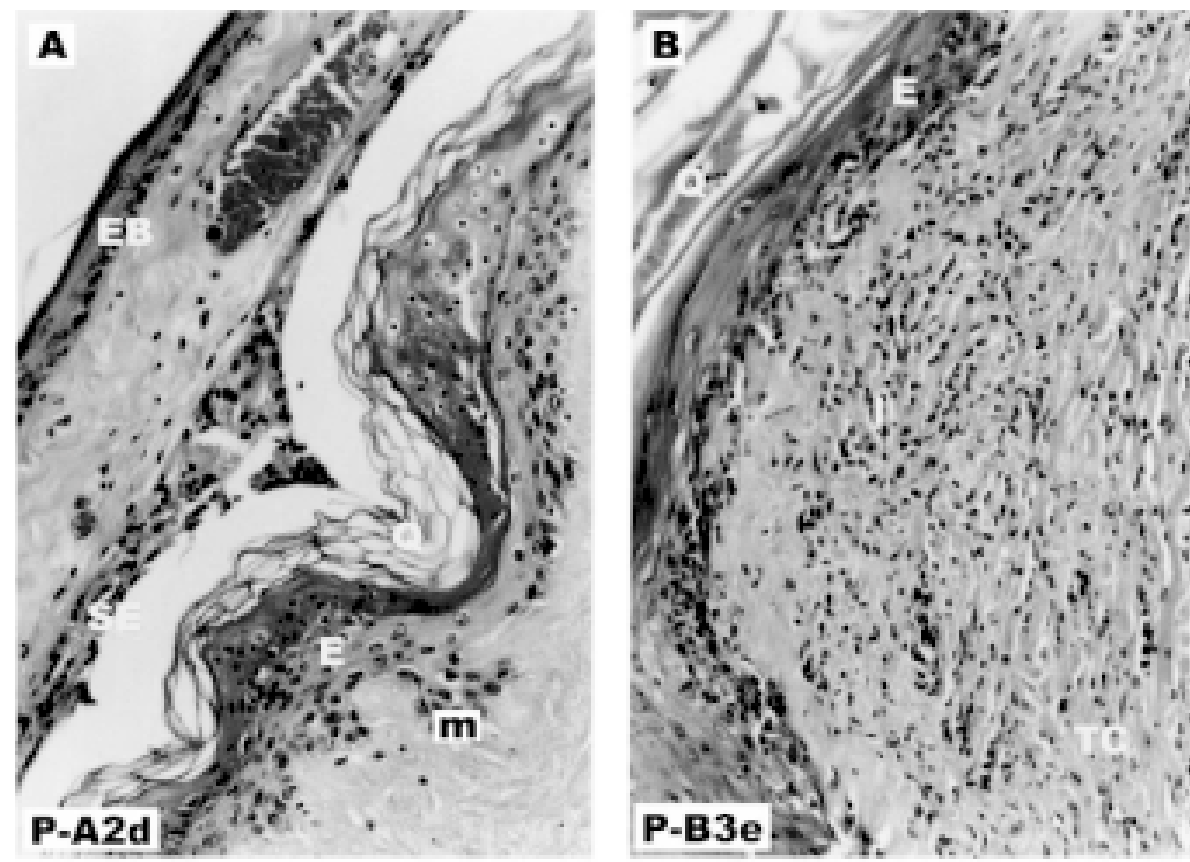

A - O epitélio da pele enxertada encontra-se íntegro, com presença de queratina e vasos no tecido conjuntivo. Observa-se desagregação dos melanócitos (m) oriundos no transplante (H.E. x 200).

B - O epitélio da pele enxertada encontra-se íntegro com queratina. Observa-se intenso infiltrado inflamatório no tecido conjuntivo (H.E. x 200).

$[\mathbf{E B}=$ Epitélio da bolsa jugal do hamster $; \mathbf{S E}=$ Subepitélio da bolsa jugal; $\mathbf{E}=$ Epitélio do fragmento enxertado; I = Infiltrado inflamatório; $\mathbf{V}=$ vaso sangüíneo no fragmento enxertado; $\mathbf{Q}=$ Queratina; $\mathbf{T C}=$ Tecido Conjuntivo.]

FIGURA 8 - Aspecto microscópico da pele normal enxertada aos 5 e 12 dias. 
Até o Grupo C (21 dias) ainda observou-se um infiltrado inflamatório, porém mais tênue, e a presença de um epitélio íntegro na pele enxertada. Nos grupos seguintes não foi observado epitélio íntegro, mas resquícios destes ou epitélios dismorfos. Em 6 fragmentos integrados, o epitélio estava ausente, observando-se tecido conjuntivo com vasos (amostras
P-B2d, P-B3d, P-C2e, P-D2e, P-E1e e P-F2d) Melanócitos foram observados a partir do Grupo D (42 dias), e o tecido conjuntivo apresentou um início de hialinização. A partir do Grupo E (84 dias), as fibras colágenas do tecido conjuntivo deixaram de apresentar seu aspecto normal em bandas, tornando-se hialinizadas (Figura 9).
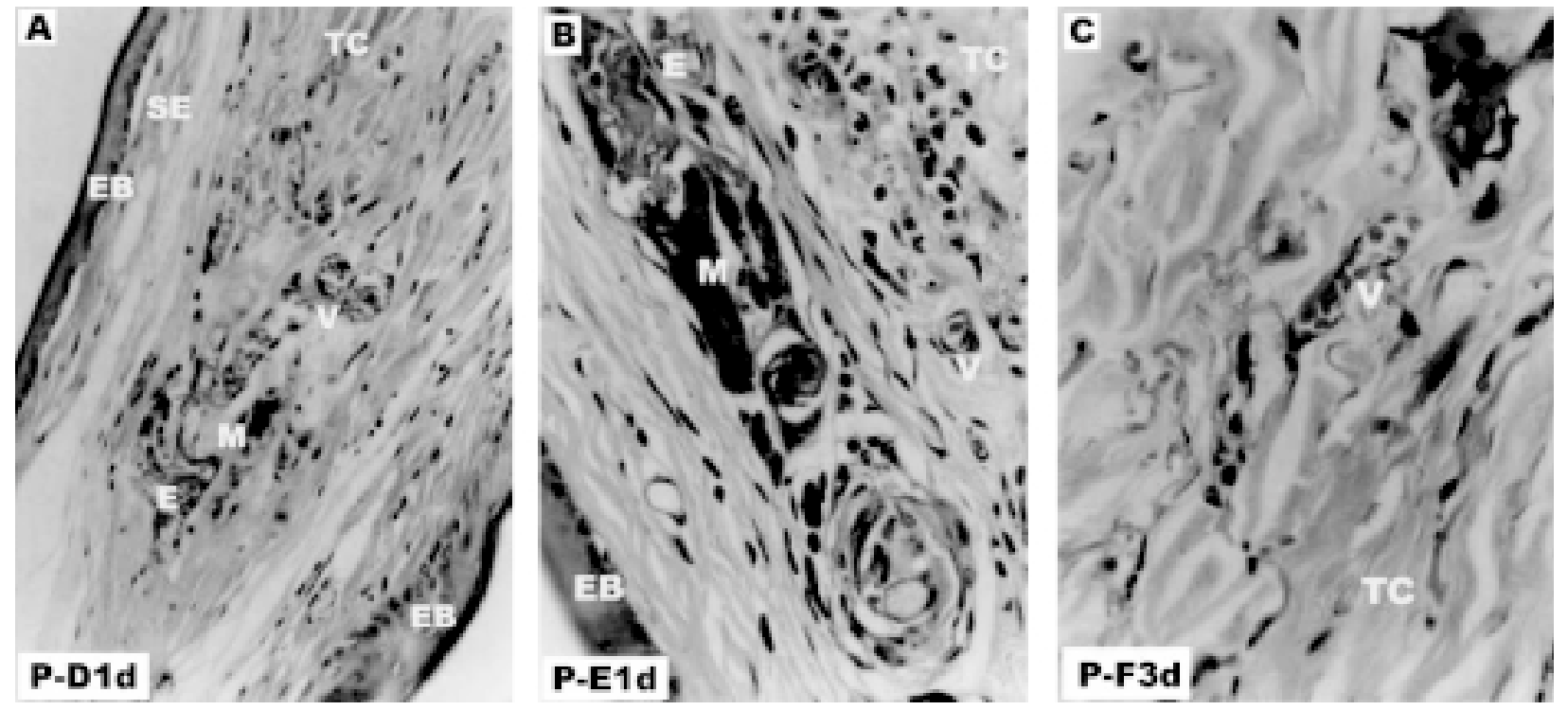

FIGURA 9 - Aspecto microscópico da pele enxertada aos 42, 84 e 168 dias

A - Aos 42 dias, epitélio dismorfo com presença de melanócitos e tecido conjuntivo em fase inicial de hialinização, com presença de vasos sangüíneos (H.E. x 200).

B - Epitélio dismorfo com melanócitos, com tecido conjuntivo vascularizado (H.E. x 400).

C - Tecido conjuntivo hialinizado com vasos sangüíneos (H.E. x 400).

$[\mathbf{E B}=$ Epitélio da bolsa jugal do hamster $; \mathbf{S E}=$ Subepitélio da bolsa jugal $; \mathbf{E}=$ Epitélio do fragmento enxertado; $\mathbf{V}=$ vaso sangüíneo no fragmento enxertado; $\mathbf{M}=$ Melanócitos; $\mathbf{T C}=$ Tecido Conjuntivo.]

Os resultados histológicos dos enxertos de pele estão descritos na Tabela 3 e na Figura 10.

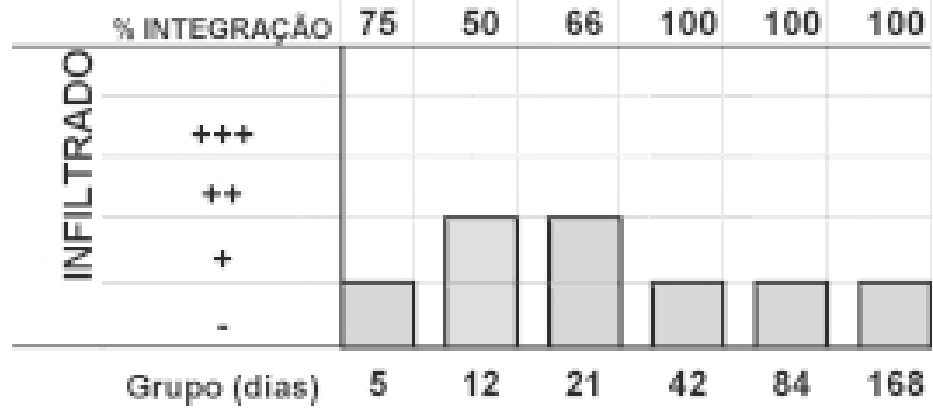

FIGURA 10 - Exame histológico nos enxertos de pele, por grupo, com a freqüência de integração e presença de infiltrado.

Representação das observações histológicas dos grupos, por período de 5 , $12,21,42,84$ e 168 dias, referente à porcentagem relativa de integração e da presença de infiltrado inflamatório nos enxertos de pele normal. 
TABELA 3 - Descrição dos exames histológicos nos enxertos de pele.

\begin{tabular}{|c|c|c|c|c|c|c|c|}
\hline $\begin{array}{l}\text { SUB- } \\
\text { GRUPO } \\
\text { (dias) }\end{array}$ & $\begin{array}{c}\text { AMOSTRA } \\
\text { DE } \\
\text { PELE }\end{array}$ & $\begin{array}{c}\text { INTE- } \\
\text { GRAÇÃO }\end{array}$ & $\begin{array}{c}\text { VASOS } \\
\text { ( A ) }\end{array}$ & INFILTRADO & $\begin{array}{c}\text { MELANÓCITOS } \\
\text { ( C ) }\end{array}$ & $\begin{array}{l}\text { EPITELIO } \\
\text { ( D ) }\end{array}$ & $\begin{array}{c}\text { ASPECTO } \\
\text { COLÁGENO } \\
\text { ( E ) }\end{array}$ \\
\hline 5 & P-A1d & - & - & + & - & - & Normal \\
\hline 5 & P-A1e & $\varnothing$ & 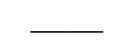 & — & - & - & - \\
\hline 5 & $\mathrm{P}-\mathrm{A} 2 \mathrm{~d}$ & + & + & - & - & Íntegro & Normal \\
\hline 5 & P-A2e & $\varnothing$ & - & - & - & & 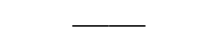 \\
\hline 5 & P-A3d & + & + & - & - & Íntegro & Normal \\
\hline 5 & $\mathrm{P}-\mathrm{A} 3 \mathrm{e}$ & + & + & - & - & Íntegro & Normal \\
\hline 12 & P-B1d & - & - & + & - & - & Normal \\
\hline 12 & P-B1e & - & - & + & - & - & Normal \\
\hline 12 & P-B2d & + & + & + & - & Ausente & Normal \\
\hline 12 & $\mathrm{P}-\mathrm{B} 2 \mathrm{e}$ & - & - & + & - & - & Normal \\
\hline 12 & P-B3d & + & + & + & - & Ausente & Normal \\
\hline 12 & $\mathrm{P}-\mathrm{B} 3 \mathrm{e}$ & + & + & + & - & Íntegro & Normal \\
\hline 21 & $\mathrm{P}-\mathrm{C} 1 \mathrm{~d}$ & + & + & + & - & Dismorfo & Normal \\
\hline 21 & $\mathrm{P}-\mathrm{C} 1 \mathrm{e}$ & - & - & + & - & - & Normal \\
\hline 21 & $\mathrm{P}-\mathrm{C} 2 \mathrm{~d}$ & - & - & - & - & - & Normal \\
\hline 21 & $\mathrm{P}-\mathrm{C} 2 \mathrm{e}$ & + & + & + & - & Ausente & Normal \\
\hline 21 & $\mathrm{P}-\mathrm{C} 3 \mathrm{~d}$ & + & + & - & - & Dismorfo & Normal \\
\hline 21 & $\mathrm{P}-\mathrm{C} 3 \mathrm{e}$ & + & + & + & + & Íntegro & Normal \\
\hline 42 & P-D1d & + & + & - & + & Resquício & Normal \\
\hline 42 & P-D1e & + & + & - & + & Resquício & Normal \\
\hline 42 & P-D2d & $\varnothing$ & 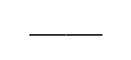 & 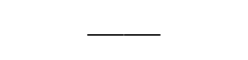 & - & - & - \\
\hline 42 & P-D2e & + & + & - & - & Ausente & Hialinizado \\
\hline 42 & P-D3d & + & + & - & + & Resquício & Normal \\
\hline 42 & P-D3e & $\varnothing$ & - & - & - & - & $\longrightarrow$ \\
\hline 84 & P-E1d & + & + & - & + & Dismorfo & Hialinizado \\
\hline 84 & P-E1e & + & + & - & - & Ausente & Hialinizado \\
\hline 84 & P-E2d & + & + & - & + & Dismorfo & Hialinizado \\
\hline 84 & $P-E 2 e$ & + & + & - & + & Dismorfo & Hialinizado \\
\hline 84 & P-E3d & + & + & - & + & Dismorfo & Hialinizado \\
\hline 84 & P-E3e & + & + & - & + & Resquício & Hialinizado \\
\hline 168 & P-F1d & + & + & - & - & Dismorfo & Hialinizado \\
\hline 168 & P-F1e & + & + & - & - & Dismorfo & Hialinizado \\
\hline 168 & P-F2d & + & + & - & - & Ausente & Hialinizado \\
\hline 168 & $\mathrm{P}-\mathrm{F} 2 \mathrm{e}$ & $\varnothing$ & 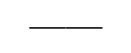 & - & - & - & $\longrightarrow$ \\
\hline 168 & P-F3d & + & + & - & + & Resquício & Hialinizado \\
\hline 168 & $\mathrm{P}-\mathrm{F} 3 \mathrm{e}$ & + & + & - & + & Dismorfo & Hialinizado \\
\hline
\end{tabular}

Legenda:

$\boldsymbol{\emptyset}=$ ausência do fragmento enxertado na lâmina

$+=$ presença; $-=$ ausência 


\section{Discussão}

A área da ciência conhecida como Imunologia dos Transplantes tem evoluído rapidamente. A pele humana, entre os heteroenxertos, constitui-se num dos tecidos mais utilizados para a compreensão dos fenômenos de integração e rejeição dos transplantes, devido às propriedades imunogênicas próprias desse tecido.

Neste estudo procurou-se detalhar o processo de integração do heteroenxerto de pele humana num "Local de Privilégio Imunológico", em animal pouco utilizado na literatura para esta finalidade, apesar de ser portador de um sistema imune intacto in natura, em detrimento aos animais criados pela Bioengenharia Genética.

Adotou-se como critério histológico de integração a presença de vasos sangüíneos na região periférica e central dos fragmentos enxertados. Nesse contexto, Haller, Billingham (1967), ${ }^{(15)}$ descreveram que enxertos de pele no subepitélio da bolsa jugal do hamster, até o $5^{\circ}$ dia, apresentam vasos pletóricos, porém com ausência de fluxo sangüíneo. Os enxertos seriam nutridos nesse período por embebição, podendo evoluir para necrose ou para a efetiva integração. Após o $6^{\circ}$ dia, e até 28 dias após o transplante, a presença de uma circulação dinâmica em vasos com o mesmo padrão morfológico aos originais, sugeriram fortemente a possibilidade de que esses vasos foram oriundos de brotos capilares do leito receptor invadindo o enxerto por um processo de inosculação. Portanto, após o $6^{\circ}$ dia, a presença no tecido enxertado de vasos sangüíneos não pletóricos, de aspecto normal e contendo hemácias, viabiliza o critério vascular adotado neste estudo como parâmetro seguro do processo de integração. Outras observações realizadas, como a presença de melanócitos ou queratina, auxiliam a validar o processo de integração em fases mais tardias. ${ }^{(14)}$

Os resultados deste estudo, em relação à vascularização dos fragmentos enxertados, apresentaram semelhanças com outros da literatura. Foi observada uma vascularização circunjacente aos enxertos de pele no grupo de 5 dias, que tenuamente intensificou-se no grupo de 12 dias, não sendo mais detectada nos outros grupos. Nishioka, Ryan (1972), ${ }^{(18)}$ transplantaram células de epiderme de hamsters neonatos envoltas com Millipore $^{\circledR}$ na bolsa do hamster, e observaram uma proliferação vascular similar àquela que ocorreu nos enxertos de pele humana deste estudo, num raio de $3 \mathrm{~mm}$ ao redor da pele enxertada. Resultados semelhantes foram obtidos por Wolf, Harrison (1973), ${ }^{(19)}$ após 3 dias de transplante, com células de epiderme da pele de hamsters adultos.

Em relação à presença dos ramos vasculares em direção ao fragmento de pele enxertado na bolsa jugal, não existe relato prévio na literatura. Apenas no camundongo atímico, à macroscopia, os enxertos de quelóide e cicatriz hipertrófica também foram vistos sendo supridos por um ramo arterial subcutâneo, geralmente único. ${ }^{(20)}$

Nos grupos de 5 e 12 dias houve associação entre os achados macroscópicos e microscópicos, em relação à vascularização mais ativa coincidindo com a presença de infiltrado inflamatório nessas fases. Porém, houve relação inversa referente ao fato de uma vascularização macroscópica mais intensa dos fragmentos enxertados não ser correspondida, do ponto de vista vascular, ao exame microscópico nesses grupos de 5 e 12 dias.

Embora não tenha sido objeto deste estudo a avaliação da dinâmica da microcirculação, esse resultado aparentemente paradoxal, estaria coerente com os achados de Kischer et al (1989) ${ }^{(20)}$ em camundongos atímicos transplantados com pele humana e quelóide, e Waki, Crumley (1991), ${ }^{(21)}$ em hamsters transplantado com pele. Esses autores descreveram que, a partir de 21 dias, ocorreria o aparecimento de microanastomoses entre o fragmento enxertado e o leito receptor. Com o suprimento microvascular garantido a partir dessa fase, não haveria mais a necessidade de uma oferta macrovascular para garantir a sobrevivência do fragmento que a fase inicial mais crítica exigia (grupos de 5 e 12 dias). Os exames histológicos dos grupos seguintes corroborariam esse fato, pelo aumento gradual de capilares a partir de 21 dias de transplante, em oposição com a ausência de alterações vasculares macroscópicas na bolsa até o fim do estudo.

Em decorrência dos fenômenos vasculares acima citados em camundongos atímicos e hamsters, foram escolhidos neste estudo os períodos de eutanásia dos animais para exame dos fragmentos enxertados, aos 5, 12 e 21 dias (Grupos A, B e C, respectivamente). Até o $5^{\circ}$ dia (Grupo A), o fragmento de pele no subepitélio da bolsa do hamster é mantido por embebição plasmática, ${ }^{(15)}$ representando o período mais crítico. Porém, o diagnóstico definitivo da sobrevivência ou necrose do enxerto é definida em torno do $10^{\circ}$ dia nos enxertos de pele em camundongos atímicos. ${ }^{(22)}$ Durante esse período os fragmentos enxertados apresentam graus variáveis de infiltração linfocitária, podendo mascarar a vitalidade do enxerto. Por isso, determinouse o $12^{\circ}$ dia (Grupo B) para examinar as bolsas. A escolha do $21^{\circ}$ dia (Grupo C) foi baseada na ocorrência das microanastomoses vasculares, nesse período, nos heteroenxertos de pele humana e quelóide no camundongo atímico. ${ }^{(20,21)}$ Os períodos dos outros grupos foram determinados seguindo a tendência, de estudos de heteroenxertos de pele e quelóide no camundongo 
atímico, de obter observações em prazos mais prolongados. $^{(20,23)}$

Nos Grupos A, B e C também houve infiltração celular tipo inflamatória. Esse efeito leucocitário já foi descrito no camundongo atímico, onde também ocorre um infiltrado celular inespecífico difuso na primeira semana após a heteroenxertia de pele humana. Essa infiltração celular deu margem, nos primórdios das investigações dos animais atímicos, de ser falsamente diagnosticada como rejeição do fragmento enxertado. ${ }^{(5)}$ Porém, passado esse período inicial de transplante, verificou-se que o infiltrado diminuia sensivelmente e comprovou-se que os enxertos integravam-se. Nesse sentido, a administração de córtico-esteróides em hamsters diminuiu ou suprimiu o infiltrado, porém, sem que houvesse uma repercussão adicional favorável no prognóstico de integração dos enxertos. ${ }^{(14)}$

Neste estudo também houve a impressão inicial, nos grupos de 5 e 12 dias, que poderia não ocorrer integração da maioria dos fragmentos enxertados. Esse fato refletiu-se nos índices obtidos de integração dos fragmentos de pele enxertados. No grupo de 5 dias foi de $75 \%$, e no grupo de 12 dias o índice foi de $50 \%$. A partir do grupo de 21 dias os índices foram de $100 \%$ até o grupo de 168 dias. Portanto, os baixos índices iniciais obtidos de integração não representaram a realidade dos fatos. De outra forma, se os animais dos grupos de 5 e 12 dias nos quais foi considerado que não houve integração do fragmento enxertado, fossem hipoteticamente sacrificados mais tardiamente, poderse-ia diagnosticar que houve de fato integração desses mesmos fragmentos outrora considerados não integrados.

Sendo o subepitélio da bolsa do hamster um conhecido "Local de Privilégio Imunológico", e o camundongo atímico um modelo experimental com consagrada imunodeficiência e apto a receber heteroenxertos, essa infiltração leucocitária em ambos os animais poderia ser consequiência de uma reação vascular em resposta ao trauma operatório. A presença desse infiltrado também poderia ser devida a uma precoce e incipiente reação ao transplante, porém ineficaz por uma impotência funcional dos linfócitos presentes. ${ }^{(14,18)}$

A partir do grupo de 42 dias o exame macroscópico revelou, quase invariavelmente, o aparecimento de uma área de pigmentação castanho-escura nos fragmentos enxertados. A partir do mesmo período, o exame histológico revelou a presença de melanócitos na maioria dos fragmentos de pele enxertados.

Os resultados obtidos neste estudo não foram submetidos a análise estatística devido ao reduzido tamanho amostral dos grupos. Apesar do elevado índice de integração dos fragmentos enxertados houve, paradoxalmente, uma relevante quantidade de enxertos com falta de preservação na integridade dos epitélios. De um total de 24 fragmentos enxertados e integrados de pele, 4 mantiveram seu epitélio íntegro. Resquícios de epitélio apareceram em 5 amostras, epitélio de aspecto dismorfo em 9 amostras, e esteve ausente em 6 amostras de fragmentos integrados.

Existem duas hipóteses viáveis para explicar essa relevante porcentagem de ausência de epitélio. $\mathrm{Na}$ primeira, poderia ocorrer uma absorção ou destruição total do epitélio dos fragmentos enxertados. Esta hipótese, porém, não seria completamente elucidativa, em função do epitélio estar ausente em fragmentos integrados nos grupos de 5 e 12 dias, e deste estar presente e íntegro em fragmentos de pele de até 21 dias (amostra $\underline{\mathrm{P}-\mathrm{C} 3 \mathrm{e}}$ ). A segunda hipótese, e a mais provável, é que no preparo histológico das lâminas não houve, em algumas, inclusão do epitélio do enxerto, e apenas do tecido conjuntivo da derme. Essa possibilidade é corroborada por um total de 5 lâminas $(20,83 \%)$ que apresentaram resquícios de epitélio, inclusive com a presença de melanócitos, células tipicamente epiteliais.

Apesar do cuidado de ter padronizado o preparo das bolsas para o exame microscópico, os resultados advindos desta tática não foram, a priori, suficientemente satisfatórios. Além do elevado número de fragmentos enxertados integrados com ausência ou resquícios de epitélio, em 5 bolsas contendo de fato o fragmento de pele enxertado ( $\underline{\mathrm{P}-\mathrm{A} 1 \mathrm{e}}, \underline{\mathrm{P}-\mathrm{A} 2 \mathrm{e}}, \underline{\mathrm{P}-\mathrm{D} 2 \mathrm{~d}}$, $\underline{\mathrm{P}-\mathrm{D} 3 \mathrm{e}}$ e $\underline{\mathrm{P}-\mathrm{F} 2 \mathrm{e}})$, macroscopicamente visíveis, os mesmos não foram incluídos nas lâminas na sua totalidade.

Cohen (1961) ${ }^{(14)}$ e Kreider e col. (1971) ${ }^{(6)}$ já advertiram, nesse contexto de preservação do epitélio, que o enxerto de pele integrado, ao secretar queratina no compartimento fechado do subepitélio da bolsa, delimitado pelo epitélio do fragmento enxertado e o epitélio da bolsa, originaria um encistamento de queratina. Esse encistamento acumulativo, comprimindo gradualmente o próprio epitélio do enxerto, poderia prejudicar sua estrutura histológica e deixá-lo de aspecto achatado ou dismorfo à microscopia.

Por isso, esses autores propuseram ressecar a bolsa do seu local original, secioná-la longitudinalmente evitando lesar vasos, e transplantá-la aberta no dorso do animal, em espaço previamente preparado pela remoção de pele em igual dimensão ao autoenxerto, com a superfície do subepitélio voltada exteriormente. Sobre esta superfície realizaram as enxertias, sem o possível inconveniente do encistamento autocompressivo da queratina. Desde que não houvesse contato direto do fragmento de pele enxertado com os tecidos circunvizinhos do dorso do animal, ou com a sutura circular do fragmento de bolsa heterotópica, com o 
intuito de evitar o estímulo antigênico, o subepitélio da bolsa manteria o status de privilégio imunológico. ${ }^{(6,15,24)}$

Neste estudo, a integração mais tardia dos fragmentos de pele enxertados, com epitélio íntegro, atingiu 21 dias ( $\underline{\mathrm{P}-\mathrm{C} 3 \mathrm{e}})$. A longo prazo, alcançaram 168 dias de sobrevivência, com produção ativa de melanina, mesmo em fragmentos de pele com epitélios dismorfos. Nessa fase tardia, apesar da estrutura das fibras colágenas do enxerto estar hialinizada, observou-se a presença de vasos no tecido conjuntivo, denotando um metabolismo celular ainda ativo.

Em relação à longevidade de heteroenxertos de pele, Cohen $(1961)^{(14)}$ descreveu na bolsa jugal do hamster uma sobrevivência, com integridade histológica do epitélio, de até 42 dias. Kreider e col. (1971) ${ }^{(6)}$ relataram sobrevivência do heteroenxerto de pele até 56 dias. Reed, Manning (1973), ${ }^{(22)}$ registraram uma sobrevida de heteroenxertos de pele humana, fixados externamente na região escapular de camundongos atímicos, de até 85 dias.

Perante os resultados obtidos neste estudo com o delineamento experimental utilizado, pode-se sugerir que este modelo seja utilizado para estudos de heteroenxerto de pele humana, com manutenção da integridade do epitélio, por até 21 dias. Quando não for exigida a presença de epitélios íntegros na análise das amostras enxertadas, o modelo experimental aqui descrito pode ser utilizado para estudo de heteroenxerto de pele humana por até 168 dias.

Neste estudo não houve complicações nos hamsters quanto a infecções secundárias, assim como em relação à cicatrização espontânea do epitélio das bolsas operadas, mesmo não tendo obedecido, operacionalmente, as normas convencionais de assepsia e antissepsia. Apenas houve, no subgrupo de 5 dias de transplantes de pele, uma bolsa com uma reação inflamatória mais intensa (P-A1d), e outra cuja incisão não estava completamente cicatrizada e apresentava discreta secreção (P-A3d). Na primeira foi diagnosticado, pelo exame histológico, que não houve integração. Na segunda não houve nenhum comprometimento na integração do fragmento enxertado.

Esses resultados estão de acordo com aqueles encontrados por Lemon e col. (1952), ${ }^{(25)}$ que descreveram um índice de complicações pós-operatórias, em enxertos na bolsa jugal do hamster, inferior a 5\%, também sem terem observado as normas de assepsia. Outros autores, entretanto, adicionaram profilaticamente tetraciclina ${ }^{(16)}$ ou acromicina ${ }^{(19)}$ na água ingerida pelos hamsters, embora tenham realizados suas pesquisas com as bolsas exteriorizadas.

O hamster apresenta no subepitélio da bolsa jugal um local de fácil abordagem com mínimo trauma. A dissecção é facilitada pelas paredes epiteliais da bolsa serem translúcidas, podendo-se, assim, evitar lesões de vasos e um possível contato antigênico por via sangüínea. Após ser invaginada, a parede da bolsa acomoda enxertos protegendo-os de traumatismos externos, dispensando o uso de curativos protetores no pós-operatório, e permitindo que sejam abrigados vários animais por gaiola. Ainda, esse modelo viabiliza a enxertia de ambas as bolsas simultaneamente, aumentando facilmente a quantidade de fragmentos enxertados para análise.

Trata-se de um animal de fácil obtenção, de baixo custo técnico, maior porte em relação aos camundongos, e sendo mais dócil e domesticável, facilita sua manipulação operacional. A ultra-estrutura do epitélio das bolsas é, sob o ponto de vista filogenético, similar ao epitélio cutâneo humano. Por possuirem o sistema imunológico intacto, não apresentam, naturalmente, alterações endócrinas. As fêmeas são extremamente férteis, ao contrário de fêmeas de camundongos atímicos, por exemplo, que apresentam disfunções hormonais.

Por todas as atribuições acima citadas, e pelos resultados obtidos neste estudo, torna-se mister aperfeiçoar este modelo visando que possa consagrar-se, como animal experimental, para o estudo de heteroenxertos de pele humana.

\section{Conclusões}

Fragmentos de pele total humana enxertados no subepitélio da bolsa jugal do hamster (Mesocricetus auratus), mantiveram-se vascularizados por 168 dias. O epitélio do enxerto pode ser observado íntegro até 21 dias.

Os resultados, em conjunto, permitem estabelecer a bolsa jugal do hamster como modelo de investigação da fisiologia do processo de integração de heteroenxertos de pele humana ex vivo.

\section{Referências}

1. Najarian JS. Overview of in vivo xenotransplantation studies: prospects for the future. Transplant Proc 1992; 24(2):733-8.

2. Thomas F, Araneda D, Henretta J, Pittman K, Marchman W. Extended and expanded studies of xenograft rejection in immunodeficient animals. Transplant Proc 1994; 26(3):1224-7.

3. Ferreira LM, Borsanyi JP, Benhaim P, Anthony JP, Mathes SJ, Andrews JM, Laredo Filho J. The incidence of lethal graftversus-host disease in rat limb allotransplantations. Rev Hosp Sao Paulo-Esc Paul Med 1995; 6(1/2):7-10.

4. Hochman B, Ferreira LM, Vilas Bôas F. Modelo experimental para estúdio de injerto heterólogo de piel total. In: $13^{\circ}$ Congreso de la Federación Iberolatinoamericana de Cirugia Plástica; 2000, Lima. Anais. Lima: Sociedad de Cirugía Plástica Reconstructiva y Estética del Peru; 2000. p.281-5.

5. Bonomo A, Kehn PJ, Payer E, Rizzo L, Cheever AW, Shevach EM. Pathogenesis of post-thymectomy autoimmunity. J Immunol 1995; 154:6602-11. 
6. Kreider JW, Haft HM, Roode PB. Growth of human skin on the hamster. J Invest. Dermatol 1971; 57(1):66-71.

7. Benhaim P, Anthony JP, Ferreira L, Borsanyi JP, Mathes SJ. Use of combination of low-dose cyclosporine and RS-61443 in a rat hindlimb model of composite tissue allotransplantation. Transplantation 1996;61(4):527-32.

8. Head JR, Billingham RE. Immunologically privileged sites in transplantation immunology and oncology. Perspec Biol Med 1985; 29(1):115-31

9. Barker CF, Billinghan FRS. The lymphatic status of hamster cheek pouch tissue in relation to its properties as a graft and as a graft site. J Exp Med 1971; 133:620-39.

10. Duling BR. The preparation and use of the hamster cheek pouch for studies of the microcirculation. Microvasc Res 1973; $5: 423-9$.

11. White FH, Gohari K. Cellular and nuclear volumetric alterations during differentiation of normal hamster cheek pouch epithelium. Arch Dermatol Res 1982; 273:307-18.

12. Whittle S, Swartzendruber DC, Kremer M, Squier CA, Wertz W. Lipids of hamster cheek pouch epithelium. Lipids 1997; 32(9):961-4.

13. Goldenberg DM, Steinborn W. Reduced lymphatic drainage from hamster cheek pouch. Proc Soc Exp Bio Med 1970; 135:724-6.

14. Cohen SN. Comparision of autologous and heterologous normal skin grafts in the hamster cheek pouch. Proc Soc Exp Bio Med 1961; 106:677-80

15. Haller JA, Billingham RE. Studies of the origin of the vasculature in free skin grafts. Ann Surg 1967; 166(6):896-01.
16. Wolf JE, Hubler WR. Tumor angiogenic factor and human skin tumors. Arch Dermatol 1975; 111:321-7.

17. Dufour FD, Okada GT, Mah SG, Morton DL. Chemotherapy against human melanoma in the hamster cheek pouch. J Surg Oncol 1980; 15:355-61.

18. Nishioka K, Ryan TJ. The influence of the epidermis and other tissues on blood vessel growth in the hamster cheek pouch. J Invest Dermatol 1972;58(1):33-45.

19. Wolf J, Harrison RG. The angiogenic stimulus of epidermis and epidermal components on the microvasculature of the hamster cheek pouch. Bibl Anat 1973; 12:490-6.

20. Kischer CW, Pindur J, Shetlar MR, Shetlar MS. Implants of hypertrophic scars and keloids into the nude (athymic) mouse: viability and morphology. J Trauma 1989;29(5):672-7.

21. Waki EY, Crumley RL. Effects of pharmacologic agents on human keloids implanted in athymic mice. Arch Otolaryngol Head Neck Surg 1991;117:1177-81.

22. Reed ND, Manning DD. Long-term maintenance of normal human skin on congenitally athymic (nude) mice. Proc Soc Exp Biol 1973;143:350-3.

23. Shetlar MR, Shetlar CL, Hendricks L, Kischer CW. The use of athymic nude mice for the study of human keloids. Proc Soc Exp Biol Med 1985;179:549-52.

24. Billingham RE, Silvers WK. Syrian hamsters and transplantation immunity. Plast Reconstr Surg 1964;34(4):329-53.

25. Lemon HM, Lutz BR, Pope R, Parsons L, Handler AH, Patt DI. Survival and growth of human tissues transplanted to hamster cheek pouch. Science 1952; 115:461-4.

\begin{abstract}
Hochman B, Ferreira LM, Vilas Bôas F, Mariano M. Integration of human skin heterologous graft into hamster (Mesocricetus auratus) cheek pouch sub-epithelium. Acta Cir Bras [serial online] 2003 SeptOct;18(5). Available from URL: http://www.scielo.br/acb.

ABSTRACT - Purpose: To describe the integration of total human skin into hamster (Mesocricetus auratus) cheek pouch. Methods: The sample was formed by 18 male hamsters, outbred, aging between 10 and 14 weeks. Fragments of normal human skin were obtained from reduction mastoplasty of a mulatto woman patient. Each hamster was grafted into both pouches with skin fragments, in a total of 36 fragments grafted. Animals were distributed into 6 groups for examination of the grafted fragments at the days 5, 12, $21,42,84$, and 168. One macroscopic assessment was performed by comparing the pouch containing the grafted fragment in each period with the same pouch in the immediate post surgical, following standardized photographs. In the microscopic assessment, as an integration criterion of the grafted skin fragments, the presence of blood vases within the dermis was adopted. The presence of keratin, melanocytes, cellular infiltrated, and the aspect of conjunctive tissue was also observed. Results: In the macroscopic evaluation a vascular reaction in fragments up to 12 days and the presence of dark brown pigmentation up to 42 days were observed. Under microscope $80.64 \%$ of grafted fragments were integrated, including in the group of 168 days. An inflammatory cellular infiltrated was observed up to 12 days, the presence of melanocytes from 42 days and a subcutaneous cellular tissue hyalinization after 84 days were seen. Conclusions: Fragments of human skin integrate into the hamster pouch, they remain vascularized for 168 days and preserve the whole epithelium up to 21 days. The pouch sub-epithelium represents an experimental model to investigating human skin physiology ex vivo.
\end{abstract}

KEY WORDS - Mesocricetus. Transplantation, heterologous. Skin transplantation.

Conflito de interesse: nenhum

Correspondência:

Dr. Bernardo Hochman

Disciplina de Cirurgia Plástica / Departamento de Cirurgia

Universidade Federal de São Paulo

Rua Napoleão de Barros, $715 / 4^{\circ}$ andar

900-900 São Paulo - SP - Tel: (11)5576-4118

bernardohochman@uol.com.br

Data do recebimento: $12 / 07 / 2003$

Data da revisão: 21/07/2003

Data da aprovação: 02/08/2003 